\title{
Child-bearing after induced abortion: reassessment of risk
}

DANIEL S SEIDMAN, PNINA EVER-HADANI, PAUL E SLATER, SUSAN HARLAP, DAVID K STEVENSON, AND RENA GALE

From the Department of Neonatology, Bikur Cholim Hospital, Jerusalem, Israel and Department of Pediatrics, Stanford University School of Medicine, Stanford, California

SUMMARY We reviewed 1791 singleton pregnancies of women with a history of previous induced abortion and compared them with 14857 pregnancies in mothers with no previous induced abortions. Therapeutic termination of pregnancy was associated with a statistically significant increase in the incidence of low birth weight infants and bleeding in the first trimester of pregnancy. When other variables were examined, no significant differences were found between the two groups, except for a significantly higher rate of stillbirths among women who had not had a prior induced abortion. There were no increases in major or minor congenital malformations.

Induced abortion is still widely used as a birth control measure despite the availability of various prophylactic measures. It is a relatively safe procedure, but the potential for late complications, such as sterility, ectopic pregnancy, spontaneous abortion, low birth weight, and birth defects, is a major public health concern. ${ }^{1-19}$

Induced abortions are performed in Israel by qualified physicians. ${ }^{1618}$ Generally, one of two abortion methods was employed in Jerusalem at the time of this study: a dilatation and curettage or, for later abortions, intrauterine saline injections.

We report here on the complications of pregnancy, labour, and delivery, as well as outcome of pregnancy following induced abortions in Jerusalem during a 26 month survey period. As a similar analysis ${ }^{16}$ of the late sequelae of induced abortion in the Jerusalem parturient population was undertaken over a decade ago, we were able to compare these two experiences, reflecting societal changes, as well as improvements in the management of pregnancy, labour, and delivery during the period between the surveys.

\section{Population and Methods}

The reproductive histories of 16648 women with singleton births were obtained by postpartum interviews with each mother. Over $98 \%$ of the target population was interviewed. The population consisted of all live and stillborn infants born at the three largest Jerusalem obstetric units, comprising $93 \%$ of West Jerusalem births, from November 1974 through December 1976.
As obstetric services in Israel are free, virtually all $(99.5 \%)$ of the mothers received antenatal care. All births took place in a hospital setting, and high utilisation rates of mother and child health clinics ${ }^{20}$ and hospital inpatient services ${ }^{21}$ increased the likelihood that significant maternal and fetal problems were quickly and accurately recognised. Additional information about the mothers and the outcome of their pregnancies was ascertained independently from hospital records and correlated with the data from the interviews. Copies of all death certificates were received from the Ministry of Health, and a recordlinkage technique continuously updated the file with this information as well as that on congenital malformations and hospital inpatient morbidity, collected from obstetric departments, mother and child health clinics, and hospital paediatric departments throughout Israel.

The data were made available from the Jerusalem study on oral contraceptive use, ${ }^{22}$ one of the interlocking epidemiological studies comprising the Jerusalem Perinatal Study. The design and methods of the latter project have been reported elsewhere. ${ }^{23} 24$ The frequency of each variable in the study was compared to that of a control group consisting of all other women in the parturient population during the 26 months of the study.

\section{STATISTICAL ANALYSIS}

Because study and control cases (women with and without previous induced abortions, respectively) might have differed with respect to many factors, we adjusted for possible confounding variables using a 
multiple regression analysis. Despite the absence of certain theoretical requirements, ${ }^{16}$ a regression method seemed appropriate to achieve our objective of an overall survey summarising possible complications of pregnancy, labour, and delivery following induced abortions. For each outcome of pregnancy (eg, death, low birth weight, malformations) a stepwise regression analysis ${ }^{16}$ was performed placing the variable for the number of previous abortions into the equation at the first step, and continuing to incorporate other variables until none remained with a residual effect significant at the $5 \%$ level. From the resulting regression equations standardised rates were calculated for each outcome in women with or without previous induced abortions. These rates were standardised to the "average woman" of this study, ie, the mother for whom each of the other predictive variables takes its mean value.

For presentation, the crude rates for each outcome are also presented with the standardised rates and significance levels, which refer to the $t$ tests of the regression coefficients for induced abortions. A detailed account of how each variable was coded and the regression equations for each outcome of pregnancy are available from the authors.

The following variables were tested in each regression analysis, where appropriate:

-Demographic characteristics of the mother: age, formal education, ethnic origin, religion, marital status, body mass index, parity, municipal taxation level, smoking (number of cigarettes per day).

- Outcome: stillbirth, major and minor congenital malformations (defined in a previous study ${ }^{24}$ ), low birth weight of $<2500 \mathrm{~g}$, sex ratio, birth weight, gestational age.

- Complications of pregnancy: bleeding in the first trimester, $\mathrm{ABO}$ and $\mathrm{Rh}$ isoimmunisation, hypertension, toxaemia, hydramnios.

- Complications of labour: breech presentation, prolonged rupture of membranes ( $>24$ hours), placenta praevia, abruptio placentae, cord prolapse, cord anomalies, fetal distress or asphyxia, postpartum haemorrhage.
- Interventions in labour: induction, forceps delivery, vacuum extraction, caesarean section, intervention in the third stage (eg, manual removal of placenta), normal delivery (defined as vertex with none of these interventions).

\section{Results}

The study group consisted of 1791 women who reported one or more previous induced abortions. Low birth weight babies of less than $2500 \mathrm{~g}$ were born more frequently $(p<0.002)$ to women with previous induced abortions (table 1). In general, the risk for low birth weight increased with increasing number of previous induced abortions in all parity groups (table 2). The incidence of low birth weight was notably high for primiparous women and varied directly with the number of previous induced abortions.

Major and minor congenital malformations were no more common among the offspring of mothers with previous induced abortions, nor was any difference in sex ratio found. The stillbirth rate was significantly lower $(p<0.001)$ for the study group (table 1$)$.

The incidence of bleeding in the first trimester was significantly higher $(p<0.001)$ in pregnancies of women with a history of previous induced abortions. Other complications of pregnancy (table 3), including $\mathrm{ABO}$ and $\mathrm{Rh}$ isoimmunisation, toxaemia, and hydramnios, were not more common.

The frequency of complications and interventions of labour and delivery are presented in tables 4 and 5 . No statistically significant differences were found between the control and study groups. Prolonged rupture of membranes, abruptio placentae, cord anomalies, and postpartum haemorrhage (table 4) initially appeared to be more frequent among women with previous induced abortions. However, these excesses were due mainly to an unfavourable distribution of other variables (eg, maternal age, parity, and ethnic origin) in the study group.

Similarly, the crude rates of both caesarean section and obstetric intervention in the third stage of labour (table 5) were higher in the induced abortion group,

Table 1 Pregnancy outcome related to previous induced abortion

\begin{tabular}{|c|c|c|c|c|c|c|}
\hline \multirow[b]{2}{*}{ Outcome of pregnancy } & \multicolumn{3}{|c|}{ Crude rates (per 100) } & \multicolumn{3}{|c|}{ Standardised rates (per 100) } \\
\hline & $\begin{array}{l}\text { Total } \\
\text { interviewed } \\
\text { cohort }\end{array}$ & $\begin{array}{l}\text { No previous } \\
\text { induced } \\
\text { abortion }\end{array}$ & $\begin{array}{l}\geq 1 \\
\text { previous } \\
\text { abortion }\end{array}$ & $\begin{array}{l}\text { No previous } \\
\text { induced } \\
\text { abortion }\end{array}$ & $\begin{array}{l}\geq 1 \\
\text { previous } \\
\text { abortion }\end{array}$ & $\begin{array}{l}\text { Significance } \\
p\end{array}$ \\
\hline Stillbirth rate/1000 & 7.9 & $8 \cdot 5$ & $3 \cdot 4$ & $8 \cdot 4$ & $4 \cdot 9$ & $<0.001$ \\
\hline Major malformations/1000 & $10 \cdot 2$ & $10 \cdot 2$ & $10 \cdot 6$ & $10 \cdot 2$ & $10 \cdot 1$ & NS \\
\hline Minor malformations $/ 1000$ & $65 \cdot 5$ & $65 \cdot 2$ & $68 \cdot 1$ & $65 \cdot 5$ & $65 \cdot 2$ & NS \\
\hline Low birth weight $<2.5 \mathrm{~kg} / 100$ & $5 \cdot 8$ & $5 \cdot 5$ & $8 \cdot 1$ & $5 \cdot 6$ & $7 \cdot 1$ & $<0.002$ \\
\hline$\%$ Males & 52.0 & $52 \cdot 1$ & $51 \cdot 2$ & $52 \cdot 0$ & $52 \cdot 0$ & NS \\
\hline Total singleton births & 16648 & 14857 & 1791 & 14857 & 1791 & \\
\hline
\end{tabular}


296 Daniel S Seidman, Pnina Ever-Hadani, Paul E Slater, Susan Harlap, David K Stevenson, and Rena Gale but again the differences disappeared after controlling for confounding variables.

\section{Discussion}

Our large study confirms the finding of excess low birth weight among offspring born after induced abortion, while controlling for confounding variables.

Table 2 Percent of low birth weight infants according to pregnancy order and number of previous induced abortions*

\begin{tabular}{|c|c|c|c|c|c|c|c|c|c|c|}
\hline \multirow[b]{2}{*}{$\begin{array}{l}\text { No. of previous } \\
\text { induced abortions }\end{array}$} & \multicolumn{10}{|c|}{ Parity } \\
\hline & $I$ & 2 & 3 & 4 & 5 & 6 & 7 & 8 & $\geq 9$ & Total \\
\hline 0 & 6.3 & $5 \cdot 1$ & 4.6 & $5 \cdot 1$ & 6.0 & 4.7 & 5.5 & 6.3 & 5.7 & 5.5 \\
\hline 1 & & 10.8 & 5.8 & $3 \cdot 3$ & 6.7 & 5.8 & 10.5 & $14 \cdot 3$ & 7.7 & 6.8 \\
\hline 2 & & & $17 \cdot 2$ & 17.6 & 8.0 & 10.0 & 7.5 & 5.9 & 15.0 & 12.0 \\
\hline$>3$ & & & & 15.4 & 4.8 & 5.0 & 13.6 & 10.5 & 14.6 & 10.9 \\
\hline
\end{tabular}

Without regression analysis

The relevant literature has provided no consensus of opinion in this regard and has presented a variety of theories in order to explain the differences between studies. ${ }^{1-19}$

Of special interest, congenital malformations were not increased in babies born to women reporting previous induced termination of pregnancy. This is in agreement with other investigations. ${ }^{10121425}$ The Jerusalem study of the late sequelae of induced abortions, ${ }^{16}$ published over a decade ago, attracted special attention ${ }^{125}$ because it was one of the few studies that found a significantly higher rate of major and minor malformations in infants born to women with a history of previous induced abortion. The explanation for this finding was not apparent from analysis of the data. In the present study from Jerusalem, the use of dilatation and curettage, and the significantly higher rate of first trimester bleeding observed among women reporting previous induced abortion, were not associated with a significant

Table 3 Complications of pregnancy related to previous induced abortion

\begin{tabular}{|c|c|c|c|c|c|c|}
\hline \multirow[b]{2}{*}{ Complications of pregnancy } & \multicolumn{3}{|c|}{ Crude rates (per 100) } & \multicolumn{3}{|c|}{ Standardised rates (per 100) } \\
\hline & $\begin{array}{l}\text { Total } \\
\text { interviewed } \\
\text { cohort }\end{array}$ & $\begin{array}{l}\text { No previous } \\
\text { induced } \\
\text { abortion }\end{array}$ & $\begin{array}{l}\geq 1 \\
\text { previous } \\
\text { abortion }\end{array}$ & $\begin{array}{l}\text { No previous } \\
\text { induced } \\
\text { abortion }\end{array}$ & $\begin{array}{l}\geq 1 \\
\text { previous } \\
\text { abortion }\end{array}$ & $\begin{array}{l}\text { Significance } \\
p\end{array}$ \\
\hline Bleeding in first trimester & 15.9 & $15 \cdot 2$ & $22 \cdot 0$ & $15 \cdot 2$ & $21 \cdot 8$ & $<0.001$ \\
\hline Hypertension & $3 \cdot 2$ & $3 \cdot 2$ & $2 \cdot 8$ & $3 \cdot 2$ & $2 \cdot 9$ & NS \\
\hline ABO incompatibility & 0.6 & $0 \cdot 6$ & $0 \cdot 5$ & 0.6 & $0 \cdot 6$ & NS \\
\hline $\mathbf{R h}$ incompatibility & 0.2 & $0 \cdot 2$ & $0 \cdot 2$ & $0 \cdot 2$ & $0 \cdot 2$ & NS \\
\hline Toxaemia & 1.4 & $1 \cdot 5$ & $1 \cdot 2$ & $1 \cdot 5$ & $1 \cdot 1$ & NS \\
\hline Hydramnios & 0.7 & 0.7 & 0.4 & 0.7 & $0 \cdot 4$ & NS \\
\hline Total singleton births & 16648 & 14857 & 1791 & 14857 & 1791 & \\
\hline
\end{tabular}

Table 4 Complications of labour related to previous induced abortion

\begin{tabular}{|c|c|c|c|c|c|c|}
\hline \multirow[b]{2}{*}{ Complications of labour } & \multicolumn{3}{|c|}{ Crude rates (per 100) } & \multicolumn{3}{|c|}{ Standardised rates (per 100) } \\
\hline & $\begin{array}{l}\text { Total } \\
\text { interviewed } \\
\text { cohort }\end{array}$ & $\begin{array}{l}\text { No previous } \\
\text { induced } \\
\text { abortion }\end{array}$ & $\begin{array}{l}\geq 1 \\
\text { previous } \\
\text { abortion }\end{array}$ & $\begin{array}{l}\text { No previous } \\
\text { induced } \\
\text { abortion }\end{array}$ & $\begin{array}{l}\geq 1 \\
\text { previous } \\
\text { abortion }\end{array}$ & $\begin{array}{l}\text { Significance } \\
p\end{array}$ \\
\hline Breech & $3 \cdot 3$ & $3 \cdot 2$ & $3 \cdot 5$ & $3 \cdot 3$ & $2 \cdot 9$ & NS \\
\hline PROM* & $5 \cdot 7$ & $5 \cdot 5$ & $7 \cdot 5$ & $5 \cdot 7$ & $6 \cdot 1$ & NS \\
\hline Placenta praevia & 0.4 & 0.4 & 0.5 & 0.4 & 0.4 & NS \\
\hline Abruptio placentae & 0.4 & 0.4 & 0.7 & 0.4 & 0.5 & NS \\
\hline Cord prolapse & 0.4 & 0.4 & 0.4 & 0.4 & 0.4 & NS \\
\hline Other cord anomalies & $9 \cdot 1$ & 8.8 & 11.4 & $9 \cdot 0$ & $10 \cdot 3$ & NS \\
\hline Fetal distress/asphyxia & 9.9 & 9.9 & $9 \cdot 9$ & $10 \cdot 0$ & $9 \cdot 4$ & NS \\
\hline Postpartum haemorrhage & $2 \cdot 6$ & 2.6 & $3 \cdot 3$ & $2 \cdot 3$ & $2 \cdot 6$ & NS \\
\hline Total singleton births & 16648 & 14857 & 1791 & 14857 & 1791 & \\
\hline
\end{tabular}

- Prolonged rupture of membranes 
Table 5 Interventions in labour by previous induced abortions

\begin{tabular}{|c|c|c|c|c|c|c|}
\hline \multirow[b]{2}{*}{ Intervention in labour } & \multicolumn{3}{|c|}{ Crude rates (per 100) } & \multicolumn{3}{|c|}{ Standardised rates (per 100) } \\
\hline & $\begin{array}{l}\text { Total } \\
\text { interviewed } \\
\text { cohort }\end{array}$ & $\begin{array}{l}\text { No previous } \\
\text { induced } \\
\text { abortion }\end{array}$ & $\begin{array}{l}\geq 1 \\
\text { previous } \\
\text { abortion }\end{array}$ & $\begin{array}{l}\text { No previous } \\
\text { induced } \\
\text { abortion }\end{array}$ & $\begin{array}{l}\geq 1 \\
\text { previous } \\
\text { abortion }\end{array}$ & $\begin{array}{l}\text { Significance } \\
p\end{array}$ \\
\hline $\begin{array}{l}\text { Normal delivery } \\
\text { (no interventions) }\end{array}$ & $59 \cdot 3$ & $59 \cdot 6$ & $57 \cdot 5$ & $59 \cdot 4$ & $58 \cdot 8$ & NS \\
\hline Induction of labour & $27 \cdot 9$ & $28 \cdot 0$ & $26 \cdot 9$ & $27 \cdot 9$ & $27 \cdot 9$ & NS \\
\hline Forceps & $2 \cdot 2$ & $2 \cdot 3$ & 1.8 & $2 \cdot 3$ & $2 \cdot 2$ & NS \\
\hline Vacuum extraction & $5 \cdot 4$ & $5 \cdot 4$ & $5 \cdot 5$ & $5 \cdot 4$ & 4.9 & NS \\
\hline Caesarean section & $6 \cdot 4$ & $6 \cdot 2$ & $8 \cdot 5$ & $6 \cdot 4$ & $6 \cdot 2$ & NS \\
\hline $\begin{array}{l}\text { Intervention in 3rd stage } \\
\text { (manual removal of placenta) }\end{array}$ & 3.7 & 3.6 & $4 \cdot 5$ & $3 \cdot 7$ & 3.6 & NS \\
\hline Total singleton births & 16648 & 14857 & 1791 & 14857 & 1791 & \\
\hline
\end{tabular}

increase in the rate of major or minor congenital malformations in the offspring of pregnancies following induced abortion.

Further comparison of the two Jerusalem studies reveals an increase in the number of women with a history of previous abortions over the eight year period $(10.8 \% v 6.8 \%)$. Both studies found an increase in the low birth weight rate and in the incidence of bleeding in the first trimester of pregnancy for women with previous induced abortions. However, the present study did not reveal a significant increase in third stage obstetric interventions, and the decrease in stillbirth rate was not shown to be significant for the study group in the former study. ${ }^{16}$

The present study may have been affected by several sources of bias. ${ }^{1}$ Selection bias probably did not have a strong influence on our data because both control and study groups belonged to the same predefined target population. Aborters were identified through interview of almost all $(98 \%)$ women in the target population. Identifying previous aborters by interview might have introduced a recall bias, as women with a normal subsequent pregnancy experience could preferentially fail to report a previous abortion even when questioned directly. ${ }^{16}$ An attempt to quantify the under-reporting of abortions in Jerusalem at the time of our study has been undertaken. ${ }^{26}$ One sixth of a group of women who underwent induced abortion and subsequently gave birth denied the abortions in a medical interview. It follows that the control group could include a small proportion of women who did, in fact, have induced abortions. If this were true, the results would probably underestimate the true risk of undesirable sequelae. ${ }^{16}$ On the other hand, a possible information bias ${ }^{1}$ might lead to an overestimation of the danger of induced abortion, as women are more likely to report previous induced abortions if they have subsequently suffered an adverse outcome ${ }^{1}$ or a complication of early pregnancy, ${ }^{16}$ regardless of whether the condition was actually related to the previous abortion. Such women would artifactually appear to be at higher risk for an unfavourable pregnancy outcome. ${ }^{16}$

An associated link between low birth weight and previous induced abortion does not necessarily imply that the increase in the rate of induced abortion will have an overall adverse effect on public health. While the increasing use of legal abortion was related to an increase in low birth weight in Hungary, ${ }^{27} 28$ an opposite relation was reported from the US. ${ }^{29}$ The number of infants born to parents of low social class has been proposed as the explanation for the overall increase of post-abortion low birth weight recorded in Hungary. ${ }^{27}$ In contrast, the subsidised family planning services for low income women and the increase in the legal abortion rate in the US has led to a reduction of neonatal mortality ${ }^{30}$ and low birth weight rate. ${ }^{29}$ It seems that liberalisation of abortion laws, combined with comprehensive family planning programmes might have an overall beneficial effect for society, even in the light of seemingly harmful effects on childbearing following induced abortions.

Reprint requests: David K Stevenson, MD, Department of Pediatrics, Stanford University School of Medicine, Stanford, CA 94305, USA

\section{References}

${ }^{1}$ Cates W. Late effects of induced abortion. Hypothesis or knowledge? J Reprod Med 1979; 22: 207-12.

${ }^{2}$ Meirik O, Nygren KG. Outcome of first delivery after 2 nd trimester two-stage induced abortion. Acta Obstet Gynecol Scand 1984; 63: 45-50. 
298 Daniel S Seidman, Pnina Ever-Hadani, Paul E Slater, Susan Harlap, David K Stevenson, and Rena Gale

${ }^{3}$ MacKenzie IZ, Hillier K. Prostaglandin-induced abortion and outcome of subsequent pregnancies: a prospective controlled study. $\mathrm{Br} \mathrm{Med} J$ 1977; 2: 1114.

${ }^{4}$ Meirik O, Bergstrom R. Outcome of delivery subsequent to vacuum-aspiration abortion in nulliparous women. Acta Obstet Gynecol Scand 1983; 62: 499-500.

${ }^{5}$ Park TK, Strauss LT, Hogue CJR, Kim IS. Previous experience of induced abortion as a risk factor for fetal death and preterm delivery. Int $J O b$ Gyn 1984; 22: 195-202.

${ }^{6}$ Pickering RM, Forbes JF. Risks of preterm delivery and small-for-gestational age infants following abortion: a population study. Br J Obstet Gynaecol 1985; 92: 110612.

${ }^{7}$ Dalaker K, Moe Lichtberg S, Okland G. Delayed reproductive complications after induced abortion. Acta Obstet Gynecol Scand 1979; 58: 491-4.

${ }^{8}$ Bracken MB, Hellenbrand KG, Holford TR, BryceBuchnan C. Low birth weight in pregnancies following induced abortion: no evidence for an association. $\mathrm{Am} \mathrm{J}$ Epidemiol 1986; 123: 604-13.

9 Meirik O, Nygren KG, Bergstrom R, Gunsjo A. Outcome of delivery subsequent to induced vacuum-aspiration abortion in parous women. Am J Epidemiol 1982; 116: 415-29.

${ }^{10}$ Schoenbaum SC, Monson RR, Stubblefield PG, Darney PD, Ryan KJ. Outcome of the delivery following an induced or spontaneous abortion. Am J Obstet Gynecol 1980; 136: 19-24.

11 Papaevangelou G, Vrettos AS, Papadatos C, Alexion D. The effect of spontaneous and induced abortion on prematurity and birthweight. J Obstet Gynaecol Brit Commonw 1973; 80: 418-22.

12 Daling JR, Emanuel I. Induced abortion and subsequent outcome of pregnancy. Lancet 1975; ii: 170-2.

${ }^{13}$ Roht LH, Aoyama H. Induced abortion and its sequelae: prematurity and spontaneous abortion. Am J Obstet Gynecol 1974; 120: 868-74.

14 Daling JR, Emanuel I. Induced abortion and subsequent outcome of pregnancy in a series of American women. $N$ Engl J Med 1977; 297: 1241-5.

15 Koller O, Eikhom SN. Late sequelae of induced abortion in primigravidae, the outcome of subsequent pregnancies. Acta Obstet Gynecol Scand 1977; 56: 311-7.

16 Harlap S, Davies AM. Late sequelae of induced abortion: Complications and outcome of pregnancy and labor. $\mathrm{Am}$ J Epidemiol 1975; 102: 217-27.
${ }^{17}$ Harlap S, Shiono PH, Ramcharan S, Berendes H, Pellegin F. A prospective study of spontaneous fetal losses after induced abortions. New Engl J Med 1979; 301: 677-781.

${ }^{18}$ Slater PE, Weiner D, Davies AM. Requests for abortion and outcomes of pregnancy in Jerusalem, Israel. $J$ Reprod Med 1978; 21: 279-82.

${ }^{19}$ Slater PE, Davies AM, Harlap S. The effect of abortion method on the outcome of subsequent pregnancy. $J$ Reprod Med 1981; 26: 123-8.

${ }^{20}$ Handelsman M, Halevi HS. Mother and child health stations 1971. Supplement to the State of Israel Statistical Bulletin II, 1972.

${ }^{21}$ Harlap S, Stenhouse NN, Davies AM. A multiple regression analysis of admission of infants to hospitals, a report from the Jerusalem Perinatal Study. Br J Prev Soc Med 1973; 27: 182-7.

22 Harlap S, Davies AM. The pill and births: The Jerusalem study. National Institute of Child Health and Development, Bethesda, MD, USA, 1978.

${ }^{23}$ Harlap S, Davies AM, Grover NB, Prywes R. The Jerusalem Perinatal Study: The first decade 1964-1973. Isr J Med Sci 1977; 13: 1073-82.

${ }^{24}$ Harlap S, Davies AM, Harber M, Sossman H, Prywes R, Samueloff N. Congenital malformations in the Jerusalem Perinatal Study: an overview with special reference to maternal origin. Isr J Med Sci 1971; 7: 1520-8.

25 Bracken MB, Holford TR. Induced abortion and congenital malformations in offspring of subsequent $\stackrel{\mathscr{\omega}}{+}$ pregnancies. Am J Epidemiol 1979; 109: 425-32.

${ }^{26}$ Slater PE, Davies AM. Patient recall of induced abortion. Eur J Obstet Gynecol Reprod Biol 1978; 8: 186-7.

${ }^{27}$ Czeizel A, Bognar Z, Tunsday G, Revesz P. Changes in mean birth weight and proportion of low weight births in Hungary. Br J Prev Soc Med 1970; 24: 146-53.

28 Makoi Z. The impact of abortion policy on prematurity in Hungary. Acta Paediatr Scand, Suppl 1985; 319: 84-8.

${ }^{29}$ Rovinsky JJ. Impact of a permissive abortion statute on community health care. Obstet Gynecol 1973; 41: 781-8.

${ }^{30}$ Grossman M, Jacobowitz S. Variations in infant mortality rates among countries of the United States: The roles of public policies and programs. Demography 1981; 18: 695-713. 